\title{
Electrometric Investigations on Formation of Lanthanum Molybdates as a Function of pH
}

\author{
Shiva Prasad ${ }^{*, a}$, Valderí D. Leite ${ }^{b}$, Renato A.C. de Santana ${ }^{a}$ and Joelma B. Brito ${ }^{a}$ \\ ${ }^{a}$ Departamento de Engenharia Química, Centro de Ciências e Tecnologia, Universidade Federal de Campina Grande, \\ CP 10108, 58109-970 Campina Grande-PB, Brazil \\ ${ }^{b}$ Departamento de Quuímica, CCT, Universidade Estadual da Paraíba, 58100-000 Campina Grande - PB, Brazil
}

\begin{abstract}
A natureza precisa da reação entre nitrato de lantânio e molibdato de sódio nos valores específicos do $\mathrm{pH}$ 7,6; 5,5 e 4,1 foi estudada através de técnicas eletrométricas envolvendo titulações potenciométricas e condutométricas, em meios aquoso e alcoólico, com cada reagente usado alternadamente como titulante. As inflexões e degraus bem definidas nas curvas de titulação fornecem evidências incontestáveis sobre a formação de molibdatos normal $-\mathrm{La}_{2} \mathrm{O}_{3} \cdot 3 \mathrm{MoO}_{3}$, para$\mathrm{La}_{2} \mathrm{O}_{3} .7 \mathrm{MoO}_{3}$ e octa-2 $\mathrm{La}_{2} \mathrm{O}_{3} .24 \mathrm{MoO}_{3}$ de lantânio nas vizinhanças de $\mathrm{pH} 5,9 ; 4,8$ e 4,2 respectivamente. Estudos analíticos também foram realizados sobre os precipitados de molibdatos de lantânio confirmando os resultados obtidos pelas técnicas eletrométricas.
\end{abstract}

The precise nature of the reaction between lanthanum nitrate and sodium molybdate at specific $\mathrm{pH}$ levels 7.6, 5.5 and 4.1 has been studied by means of electrometric techniques involving potentiometric and conductometric titrations, in aqueous and alcoholic media using each reagent as titrant. Well-defined breaks and inflections in the titration curves provide cogent evidence for formation and precipitation of lanthanum normal $-\mathrm{La}_{2} \mathrm{O}_{3} .3 \mathrm{MoO}_{3}$, para- $\mathrm{La}_{2} \mathrm{O}_{3} .7 \mathrm{MoO}_{3}$ and octa-2 $\mathrm{La}_{2} \mathrm{O}_{3} .24 \mathrm{MoO}_{3}$ molybdates in the vicinity of $\mathrm{pH} 5.9,4.8$ and 4.2, respectively. Analytical investigations of the precipitates of lanthanum molybdates have also been carried out, which substantiate the results of the electrometric study.

Keywords: molybdates, lanthanum molybdates, electrometry

\section{Introduction}

The chemistry of molybdenum is very prominent in both biological and industrial systems. ${ }^{1,2}$ It has been reported that certain molybdates have antiviral, including anti-AIDS, and antitumor activity. ${ }^{3}$ Although a large number of studies have been done in the field of molybdate chemistry, the chemical state of isopolymolybdates, obtained on acidification of a molybdate solution, is not well understood because of the complexity in polymerization. Jander et al. claimed existence of $\mathrm{Mo}_{3} \mathrm{O}_{11}{ }^{4-}$, $\mathrm{HMo}_{3} \mathrm{O}_{11}{ }^{3-}, \quad \mathrm{HMo}_{6} \mathrm{O}_{21}{ }^{5-}, \mathrm{H}_{2} \mathrm{Mo}_{6} \mathrm{O}_{21}{ }^{4-}, \mathrm{H}_{3} \mathrm{Mo}_{6} \mathrm{O}_{21}{ }^{3-}$, $\mathrm{H}_{7} \mathrm{Mo}_{12} \mathrm{O}_{41}{ }^{3-}, \mathrm{H}_{7} \mathrm{Mo}_{24} \mathrm{O}_{78}{ }^{5-}$ and $\mathrm{H}_{9} \mathrm{Mo}_{24} \mathrm{O}_{78}{ }^{3-}$ from diffusion and optical experiments. ${ }^{4}$ Bye claimed the existence of $\mathrm{Mo}_{7} \mathrm{O}_{24}{ }^{6-}, \mathrm{Mo}_{6} \mathrm{O}_{20}{ }^{4-}, \mathrm{Mo}_{4} \mathrm{O}_{13}{ }^{2-}$ and $\mathrm{HMo}_{6} \mathrm{O}_{20}{ }^{3-}$ by cryoscopic study. ${ }^{5}$ In 1959, Sasaki et al. ${ }^{6}$ deduced from potentiometry that the main complex formed is $\mathrm{Mo}_{7} \mathrm{O}_{24}{ }^{6-}$. Subsequently mathematical analysis was applied to potentiometric

* e-mail: prasad@deq.ufpb.br equilibrium curves, and Sasaki et al. ${ }^{7,8}$ claimed the existence of $\mathrm{Mo}_{7} \mathrm{O}_{24}{ }^{6-}, \mathrm{HMo}_{7} \mathrm{O}_{24}{ }^{5-}, \mathrm{H}_{2} \mathrm{Mo}_{7} \mathrm{O}_{24}{ }^{4-}$ and $\mathrm{H}_{3} \mathrm{Mo}_{7} \mathrm{O}_{24}{ }^{3-}$ up to a value of $\mathrm{Z}$ (average number of $\mathrm{H}^{+}$being consumed by $\mathrm{MoO}_{4}{ }^{2-}$ ) of around 1.4. Aveston et al. ${ }^{9}$ by centrifuge data could only tell that in the range studied, the species probably contain more than 6 and less than 9 Mo atoms. Sasaki et al. proposed the presence of large isopolymolybdate anions of the order of $20 \mathrm{Mo}$ in the solution of $\mathrm{Z}>1.5$. $^{7}$ Numerous species such as $\mathrm{HMoO}_{4}^{-}$, $\mathrm{H}_{2} \mathrm{MoO}_{4}, \mathrm{Mo}_{2} \mathrm{O}_{7}{ }^{2-}, \mathrm{HMo}_{3} \mathrm{O}_{11}{ }^{3-}, \mathrm{Mo}_{6} \mathrm{O}_{19}{ }^{2-}, \mathrm{Mo}_{7} \mathrm{O}_{24}{ }^{6-}$, $\mathrm{HMoO}_{24}{ }^{5-}, \mathrm{H}_{2} \mathrm{Mo}_{7} \mathrm{O}_{24}{ }^{4-}, \mathrm{Mo}_{8} \mathrm{O}_{26}{ }^{4-}, \mathrm{HMo}_{8} \mathrm{O}_{26}{ }^{3-}, \mathrm{Mo}_{12} \mathrm{O}_{37}{ }^{2-}$, $\mathrm{H}_{7} \mathrm{Mo}_{24} \mathrm{O}_{78}{ }^{5-}, \mathrm{Mo}_{36} \mathrm{O}_{112}{ }^{8-}$, etc have been reported in many recent publications. ${ }^{10-12}$

On account of the complexity of the relation of equilibria between the polyanions or due to the experimental difficulty in early works, the conclusions of earlier workers seem to be overstrained and hence it was considered worthwhile to make a careful and precise study of formation of molybdates in function of $\mathrm{pH}$ by electrometric techniques, which have provided more 
conclusive evidence on the condensation process of vanadate,,$^{13}$ antimonite, ${ }^{14}$ thiotungstate ${ }^{15}$ and tungstate anions. ${ }^{16}$ In an earlier publication Prasad and Gonçalves ${ }^{17}$ have reported the effect of $\mathrm{pH}$ change on composition of thorium molybdate. The results on formation of lanthanum molybdates as a function of $\mathrm{pH}$ are presented here.

\section{Experimental}

All the reagents including $\mathrm{La}\left(\mathrm{NO}_{3}\right)_{3}, \mathrm{Na}_{2} \mathrm{MoO}_{4} \cdot 2 \mathrm{H}_{2} \mathrm{O}$, $\mathrm{HNO}_{3}$, hydrochloric acid and ethanol of extra-pure grade were used, and their solutions were prepared with deionized distilled water. Concentration of sodium molybdate solutions was further verified by determining molybdenum with oxime as $\mathrm{MoO}_{2}\left(\mathrm{C}_{9} \mathrm{H}_{6} \mathrm{ON}\right)_{2} \cdot{ }^{18}$ Hydrochloric acid solutions were standardized with recrystallized sodium tetraborate decahydrate. ${ }^{18}$

The $\mathrm{pH}$ and conductometric measurements were carried out in the usual manner. ${ }^{17}$ Using different concentrations of the reactants, a series of potentiometric and conductometric titrations was carried out between acid $\left(\mathrm{HCl}, \mathrm{HNO}_{3}\right)$ and sodium molybdate solutions. All observations were made at the state of chemical equilibrium. The observed $\mathrm{pH}$ changes were plotted as a function of the volume of the titrant added. The inflections obtained by the curves were confirmed by the pronounced maxima in $\mathrm{dpH} / \mathrm{dV}$ graphs. The end-points in conductometric titrations were located by plotting the corrected conductance as a function of the volume of acid used. The results have been summarized in Table 1. Figure 1 of the titrations with only one acid $(\mathrm{HCl})$ at only one dilution is given for the sake of brevity.

Electrometric investigations on formation of lanthanum molybdates was realized by performing potentiometric and conductometric titrations between the solutions of lanthanum nitrate and sodium molybdate at specific $\mathrm{pH}$ levels. The variations of $\mathrm{pH}$ of $\mathrm{Na}_{2} \mathrm{MoO}_{4}$ solutions were obtained by progressive additions of determined quantities of nitric acid. Stoichiometric points were obtained from the sharp inflections in the titration curves. Each time 25 $\mathrm{mL}$ of solution was taken in the cell and thermostated at
$25.0 \pm 0.1^{\circ} \mathrm{C}$. The same concentrations of reactants were employed in both the techniques for the sake of comparison of results. The potentiometric and conductometric titration curves are plotted together in the same Figure for similar reasons and also for the sake of brevity. The titrations were performed both by direct and reverse methods at three different concentrations. The electrometric titration results on formation of different lanthanum molybdates are summarized in Table 2.

Analytical investigations on lanthanum molybdate precipitates were also carried out with a view to substantiate the electrometric results. Different lanthanum molybdates were prepared by mixing stoichiometric amounts of lanthanum nitrate solution with the respective sodium molybdate solutions at specific pH levels 7.6, 5.5 and 4.1. The precipitates obtained were washed several times with aqueous $30 \%(\mathrm{v} / \mathrm{v})$ ethanolic solution and dried in a vacuum dessicator for $40 \mathrm{~h}$. A known amount ( $c a .2 \mathrm{~g}$ ) of each of the above precipitates was dissolved in a minimum quantity of nitric acid and then analyzed quantitatively for molybdenum ${ }^{18}$ with oxime and for lanthanum ${ }^{18}$ with oxalate. The results are summarized in Table 3 .

\section{Results and Discussion}

Figure 1, curve 1 represents the changes occurring in $\mathrm{H}^{+}$concentration on the addition of $\mathrm{HCl}$ to sodium molybdate solution. It is noted that the smallest addition of the acid in the beginning causes a sharp fall in the $\mathrm{pH}$, whilst further reaction with $\mathrm{HCl}$ produces buffer action between $\mathrm{pH} 6.4$ and 5.9 showing strong affinity for the hydrogen ions in this region; subsequent addition of $\mathrm{HCl}$ shows a sudden fall in $\mathrm{pH}$ at a ratio $8 \mathrm{H}: 7 \mathrm{Mo}$ around $\mathrm{pH} 5.5$ corresponding to the stoichiometry for the formation of para $-\mathrm{Mo}_{7} \mathrm{O}_{24}{ }^{6-}$ molybdate polyanions. Further addition of acid yields one more inflection indicating the consumption of $1.5 \mathrm{~mol}$ of $\mathrm{HCl}$ per mol of $\mathrm{Na}_{2} \mathrm{MoO}_{4}$ and suggesting the formation of octa- $\mathrm{Mo}_{8} \mathrm{O}_{26}{ }^{4-}$ molybdate polyanions in the vicinity of $\mathrm{pH} 4.1$. The $\mathrm{pH}$ value of such acidified solutions became steady after a lapse of time indicating that the

Table 1. Summary of results of electrometric titrations of the acid-molybdate system. Volume of titrated solution taken in the cell $=25 \mathrm{~mL}$. ${ }^{\text {a }} \mathrm{A}$ and $\mathrm{B}$ represent the end-points observed from potentiometric and coductometric titrtions respectively

\begin{tabular}{|c|c|c|c|c|c|c|c|}
\hline \multirow{2}{*}{\multicolumn{2}{|c|}{$\begin{array}{l}\text { Concentration of solutions } \\
\qquad\left(\times 10^{3} \mathrm{~mol} \mathrm{~L}^{-1}\right)\end{array}$}} & \multicolumn{6}{|c|}{ Equivalence points $(\mathrm{mL})$ for the formation of } \\
\hline & & \multicolumn{3}{|c|}{ Paramolybdate } & \multicolumn{3}{|c|}{ Octamolybdate } \\
\hline $\mathrm{HCl}$ & $\mathrm{Na}_{2} \mathrm{MoO}_{4}$ & Clac. & $\mathrm{A}^{\mathrm{a}}$ & $\mathrm{B}^{\mathrm{a}}$ & Calc. & A & B \\
\hline 333.33 & $4^{2} 0.00^{4}$ & 3.43 & 3.42 & 3.45 & 4.50 & 4.50 & 4.50 \\
\hline 100.00 & 12.50 & 3.57 & 3.55 & 3.55 & 4.69 & 4.70 & 4.70 \\
\hline 33.33 & 2.86 & 2.45 & 2.45 & 2.47 & 3.21 & 3.20 & 3.22 \\
\hline 10.00 & 1.00 & 2.86 & 2.85 & 2.90 & 3.75 & 3.75 & 3.75 \\
\hline 4.00 & 0.45 & 3.25 & 3.25 & 3.30 & 4.26 & 4.30 & 4.30 \\
\hline
\end{tabular}


Table 2. Summary of results of electrometric study on formation of lanthanum molybdates. Volume of titreated solution taken in the cell = $25 \mathrm{~mL}$

\begin{tabular}{|c|c|c|c|c|c|}
\hline \multicolumn{2}{|c|}{$\begin{array}{l}\text { Concentration of solutions } \\
\qquad\left(\mathrm{x} 10^{3} \mathrm{~mol} \mathrm{~L}^{-1}\right)\end{array}$} & \multicolumn{3}{|c|}{$\begin{array}{l}\text { Equivalence points }(\mathrm{mL}) \\
\text { Calcd. } \\
\end{array}$} & \multirow[t]{2}{*}{$\begin{array}{l}\text { Formula } \\
\text { Supported }\end{array}$} \\
\hline & & & $\mathrm{pH}$ & Conductance & \\
\hline $\begin{array}{c}\mathrm{La}\left(\mathrm{NO}_{3}\right)_{3} \\
100.00 \\
33.33 \\
11.11\end{array}$ & $\begin{array}{c}\mathrm{Na}_{2} \mathrm{MoO}_{4} \\
13.33 \\
4.00 \\
1.43\end{array}$ & $\begin{array}{c}\text { Direct ti } \\
2.22 \\
2.00 \\
2.14\end{array}$ & $\begin{array}{l}\text { Figure } \\
2.22 \\
2.00 \\
2.15\end{array}$ & $\begin{array}{c}\text { ves } 1 \text { and } 2 \\
2.20 \\
2.00 \\
2.15\end{array}$ & $\mathrm{La}_{2} \mathrm{O}_{3} \cdot 3 \mathrm{MoO}_{3}$ \\
\hline $\begin{array}{l}6.67 \\
2.86 \\
1.33\end{array}$ & $\begin{array}{l}100.00 \\
50.00 \\
25.00\end{array}$ & $\begin{array}{r}\text { Reverse } t \\
2.50 \\
2.14 \\
2.00\end{array}$ & $\begin{array}{l}\text { Figure } \\
2.50 \\
2.15 \\
2.00\end{array}$ & $\begin{array}{c}\text { rves } 3 \text { and } 4 \\
2.50 \\
2.15 \\
2.02\end{array}$ & $\mathrm{La}_{2} \mathrm{O}_{3} \cdot 3 \mathrm{MoO}_{3}$ \\
\hline $\begin{array}{c}\mathrm{La}\left(\mathrm{NO}_{3}\right)_{3} \\
100.00 \\
33.33 \\
20.00\end{array}$ & $\begin{array}{c}\mathrm{Na}_{6} \mathrm{Mo}_{7} \mathrm{O}_{24} \\
4.44 \\
1.33 \\
1.00\end{array}$ & $\begin{array}{c}\text { Direct ti } \\
2.22 \\
2.00 \\
2.50\end{array}$ & $\begin{array}{l}\text { Figure } \\
2.22 \\
2.00 \\
2.50\end{array}$ & $\begin{array}{c}\text { ves } 1 \text { and } 2 \\
2.22 \\
2.00 \\
2.48\end{array}$ & $\mathrm{La}_{2} \mathrm{O}_{3} .7 \mathrm{MoO}_{3}$ \\
\hline $\begin{array}{l}4.00 \\
1.82 \\
1.11\end{array}$ & $\begin{array}{c}20.00 \\
10.00 \\
6.67\end{array}$ & $\begin{array}{r}\text { Reverse t } \\
2.50 \\
2.27 \\
2.08\end{array}$ & $\begin{array}{l}\text { Figure } \\
2.50 \\
2.30 \\
2.08\end{array}$ & $\begin{array}{c}\text { rves } 3 \text { and } 4 \\
2.50 \\
2.25 \\
2.10\end{array}$ & $\mathrm{La}_{2} \mathrm{O}_{3} \cdot 7 \mathrm{MoO}_{3}$ \\
\hline $\begin{array}{c}\mathrm{La}\left(\mathrm{NO}_{3}\right)_{3} \\
100.00 \\
33.33 \\
13.33\end{array}$ & $\begin{array}{c}\mathrm{Na}_{4} \mathrm{Mo}_{8} \mathrm{O}_{26} \\
6.66 \\
2.00 \\
1.00\end{array}$ & $\begin{array}{l}\text { Dire } \\
2.22 \\
2.00 \\
2.50\end{array}$ & $\begin{array}{l}\text { Is. Fig } \\
- \\
- \\
-\end{array}$ & $\begin{array}{r}\text { curve } 1 \\
2.20 \\
2.00 \\
2.48\end{array}$ & $2 \mathrm{La}_{2} \mathrm{O}_{3} \cdot 24 \mathrm{MoO}_{3}$ \\
\hline $\begin{array}{l}5.71 \\
2.67 \\
1.54\end{array}$ & $\begin{array}{l}50.00 \\
25.00 \\
12.50\end{array}$ & $\begin{array}{l}\text { Rever } \\
2.14 \\
2.00 \\
2.31\end{array}$ & $\begin{array}{l}\text { ns. Fis } \\
- \\
- \\
-\end{array}$ & $\begin{array}{c}\text { curve } 2 \\
2.15 \\
2 . .00 \\
2.28\end{array}$ & $2 \mathrm{La}_{2} \mathrm{O}_{3} \cdot 24 \mathrm{MoO}_{3}$ \\
\hline
\end{tabular}

Table 3. Summary of analytical results of the precipitates of lanthum molybdates

\begin{tabular}{|c|c|c|c|}
\hline $\begin{array}{l}\text { Proposed formula } \\
\text { of the compound }\end{array}$ & Mode of synthesis & Analysis \% : La & Found (calculated) Mo \\
\hline \multirow{3}{*}{$\mathrm{La}_{2} \mathrm{O}_{3} \cdot 3 \mathrm{MoO}_{3}$} & \multicolumn{2}{|c|}{ Analysis of the normal-molybdate precipitates. } & \multirow{3}{*}{$\begin{array}{l}38.02(37.99) \\
37.95\end{array}$} \\
\hline & Direct $^{\mathrm{a}}$ & $36.62(36.67)$ & \\
\hline & Reverse $^{a}$ & 36.71 & \\
\hline \multicolumn{3}{|c|}{ Analysis of the para-molybdate precipitates. } & \\
\hline \multirow{2}{*}{$\mathrm{La}_{2} \mathrm{O}_{3} \cdot 7 \mathrm{MoO}_{3}$} & Direct & $20.81(20.84)$ & $50.30(50.37)$ \\
\hline & Reverse & 20.88 & 50.43 \\
\hline \multicolumn{3}{|c|}{ Analysis of the octa-molybdate precipitates. } & \\
\hline \multirow{2}{*}{$2 \mathrm{La}_{2} \mathrm{O}_{3} \cdot 24 \mathrm{MoO}_{3}$} & Direct & $13.50(13.53)$ & $56.01(56.08)$ \\
\hline & Reverse & 13.57 & 56.16 \\
\hline
\end{tabular}

a Direct - Lanthanum nitrate solution added to sodium molybdate solution. Reserve - Sodium molybdate solution added to lanthanum nitrate solution.

reaction proceeds by way of some intermediate species. Each time the $\mathrm{pH}$ value was recorded only after waiting enough for its stabilization. It was noted that in the case of moderately concentrated solutions, the curves were steeper than for dilute reactants. Out of the two inflections in the curves, the one corresponding to the conversion into octamolybdate is more pronounced. These two inflections (curve 1) in the $\mathrm{pH}$ titration curves and maxima in $\mathrm{dpH} / \mathrm{dv}$ (curve 2) indicate that the addition of the acid to $\mathrm{Na}_{2} \mathrm{MoO}_{4}$ solution successively forms para-molybdate and octa- molybdate in the vicinity of $\mathrm{pH} 5.5$ and 4.1, respectively.

Conductometric titrations between $\mathrm{HCl}$ and $\mathrm{Na}_{2} \mathrm{MoO}_{4}$ solutions were also carried out using similar concentrations as in the potentiometric titrations. The observed breaks (Figure 1, curve 3) correspond to the formation of the same polyanions, para- $\mathrm{Mo}_{7} \mathrm{O}_{24}{ }^{6-}$ and octa $-\mathrm{Mo}_{8} \mathrm{O}_{26}{ }^{4-}$, as suggested by the preceding potentiometric study. The slow increase in conductance values on addition of $\mathrm{HCl}$ to $\mathrm{Na}_{2} \mathrm{MoO}_{4}$ solution till the point $8 \mathrm{H}: 7 \mathrm{Mo}$ may be ascribed to the formation of the highly charged $\mathrm{Mo}_{7} \mathrm{O}_{24}{ }^{6-}$ anions of the 


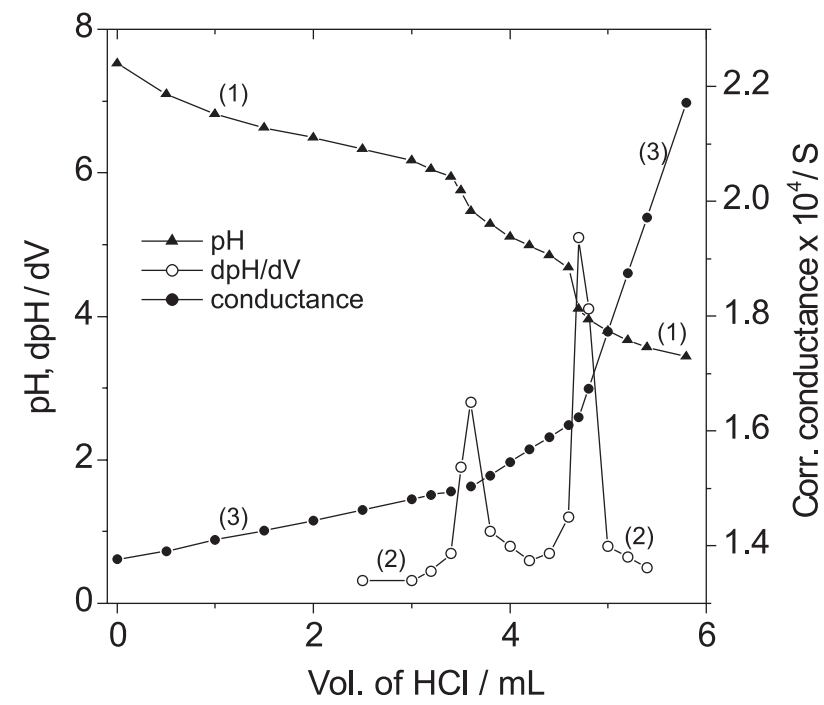

Figure 1. Potentiometric (curves 1 and 2) and conductometric (curve 3) titrations of acid-molybdate system. $25 \mathrm{~mL}$ of $1.25 \times 10^{-2} \mathrm{~mol} \mathrm{~L}^{-1}$ $\mathrm{Na}_{2} \mathrm{MoO}_{4}$ titrated with $1.00 \times 10^{-1} \mathrm{~mol} \mathrm{~L}^{-1} \mathrm{HCl}$.

relatively weak acid. The break corresponding to $1.5 \mathrm{~mol}$ of $\mathrm{HCl}$ per mol of $\mathrm{Na}_{2} \mathrm{MoO}_{4}$ is strongly defined, after which a sharp rise in conductance was observed which was determined to be the same as expected for the addition of free $\mathrm{HCl}$ to the system.

The stepwise condensation of $\mathrm{MoO}_{4}{ }^{2-}$ by gradual addition of the acids can be represented by the following equations:

$$
\begin{aligned}
& 8 \mathrm{H}^{+}+7 \mathrm{MoO}_{4}{ }^{2-}=\mathrm{Mo}_{7} \mathrm{O}_{24}{ }^{6-}+4 \mathrm{H}_{2} \mathrm{O} \\
& 12 \mathrm{H}^{+}+8 \mathrm{MoO}_{4}^{2-}=\mathrm{Mo}_{8} \mathrm{O}_{26}{ }^{4-}+6 \mathrm{H}_{2} \mathrm{O}
\end{aligned}
$$

The existence of $\mathrm{Mo}_{7} \mathrm{O}_{24}{ }^{6-}$ and $\mathrm{Mo}_{8} \mathrm{O}_{26}{ }^{4-}$ is in conformity with the results of the temperature-jump studies by Honing and Kustin ${ }^{19}$ and the Raman spectra studies by Ozeki et al..$^{20}$ Murata et al..${ }^{21}$ however, claimed that the octa-molybdate underwent further reaction with acid $\left(\mathrm{Z} \geq 1.7\right.$ ) to form $\mathrm{Mo}_{12} \mathrm{O}_{37}{ }^{2-}$ and $\mathrm{Mo}_{6} \mathrm{O}_{19}{ }^{6-}$, but this observation could not be confirmed by our results.

When a dilute solution of $\mathrm{MoO}_{4}^{2-}\left(<10^{-4} \mathrm{~mol} \mathrm{~L}^{-1}\right)$ is acidified, it yields $\mathrm{HMO}_{4}^{-}$and " $\mathrm{H}_{2} \mathrm{MoO}_{4}$ ". It has been confirmed ${ }^{10,22}$ that the tetrahedral ion $\mathrm{MoO}_{4}{ }^{2-}$ transforms into an octahedral species at the stage of second protonation.

$$
\begin{aligned}
& \mathrm{MoO}_{4}{ }^{2-}+\mathrm{H}^{+}=\left[\mathrm{MoO}_{3}(\mathrm{OH})\right]^{-} \\
& {\left[\mathrm{MoO}_{3}(\mathrm{OH})\right]^{-}+\mathrm{H}^{+}+2 \mathrm{H}_{2} \mathrm{O}=\mathrm{Mo}(\mathrm{OH})_{6} \text { or }} \\
& \mathrm{MoO}_{2}(\mathrm{OH})_{2}\left(\mathrm{H}_{2} \mathrm{O}\right)_{2}
\end{aligned}
$$

When a basic molybdate solution at millimolar or higher concentrations is acidified, the molybdate ions have been found to condense in definite steps, as evidenced by the foregoing electrometric study, to form different isopolymolybdate species. The condensation process may be considered as a rapid aggregation of the protonated species. Six monoprotonated $\left[\mathrm{MoO}_{3}(\mathrm{OH})\right]^{-}$can easily link to the diprotonated species, each one sharing a weak corner of octahedral $\mathrm{Mo}(\mathrm{OH})_{6}$. And, when six tetrahedra have been accommodated, all of these peripheral tetrahedra can expand to octahedra simply by folding at the common corners to share the octahedral edge along with a considerable decrease in enthalpy. ${ }^{10,12}$ This negative enthalpy change can be expected to stabilize the resultant product $\mathrm{Mo}_{7} \mathrm{O}_{24}{ }^{6-}$.

$$
\mathrm{Mo}(\mathrm{OH})_{6}+6\left[\mathrm{MoO}_{3}(\mathrm{OH})\right]^{-}=\mathrm{Mo}_{7} \mathrm{O}_{24}{ }^{6-}+6 \mathrm{H}_{2} \mathrm{O}
$$

The condensation process, for formation of the unprotonated polyanions, may be represented by the following general equation:

$a \mathrm{H}^{+}+b \mathrm{MoO}_{4}{ }^{2-}=\left(\mathrm{MoO}_{4}{ }^{2-}\right)_{\mathrm{b}-\mathrm{a} / 2}\left(\mathrm{MoO}_{3}\right)_{\mathrm{a} / 2}+(a / 2) \mathrm{H}_{2} \mathrm{O}$

The values of $a$ and $b$ are 8 and 7 for heptamer and 12 and 8 for octamer, respectively.

\section{Formation of lanthanum molybdates}

The electrometric and analytical investigations on the formation of lanthanum molybdates have been carried out by the interaction of lanthanum nitrate with different sodium molybdates. Sodium para-molybdate ( $\mathrm{pH}$ 5.5) and octa-molybdate $(\mathrm{pH} 4.1)$ solutions were prepared by the action of $\mathrm{Na}_{2} \mathrm{MoO}_{4}$ solutions with $\mathrm{HNO}_{3}$ in the molar ratios $7 \mathrm{Mo}: 8 \mathrm{H}$ and $8 \mathrm{Mo}: 12 \mathrm{H}$, respectively.

$7 \mathrm{Na}_{2} \mathrm{MoO}_{4}+8 \mathrm{HNO}_{3}=\mathrm{Na}_{6} \mathrm{Mo}_{7} \mathrm{O}_{24}+8 \mathrm{NaNO}_{3}+4 \mathrm{H}_{2} \mathrm{O}$

$8 \mathrm{Na}_{2} \mathrm{MoO}_{4}+12 \mathrm{HNO}_{3}=\mathrm{Na}_{4} \mathrm{Mo}_{8} \mathrm{O}_{26}+12 \mathrm{NaNO}_{3}+6 \mathrm{H}_{2} \mathrm{O}$

\section{Lanthanum normal-molybdate}

Using different concentrations of $\mathrm{Na}_{2} \mathrm{MoO}_{4}(\mathrm{pH}$ 7.6) and lanthanum nitrate $(\mathrm{pH} 4.3)$ solutions, a series of potentiometric titrations was carried out. In direct titrations (Figure 2, curve 1), when $\mathrm{Na}_{2} \mathrm{MoO}_{4}$ solution was used as titre, a gradual decrease in $\mathrm{pH}$ value was observed till at the stoichiometric end-point (the stage at which the reaction ends if simple double decomposition takes place) a sharp fall in $\mathrm{pH}$ was observed when the molar ratio of $\mathrm{La}^{3+}: \mathrm{MoO}_{4}^{2-}$ is $2: 3$ corresponding to the formation of lanthanum normalmolybdate, $\mathrm{La}_{2} \mathrm{O}_{3} \cdot 3 \mathrm{MoO}_{3}$, in the neighborhood of $\mathrm{pH}$ 5.9. In case of inverse titrations (Figure 2, curve 3), the $\mathrm{pH}$ at first gradually increases till in the vicinity of stoichiometric end- 

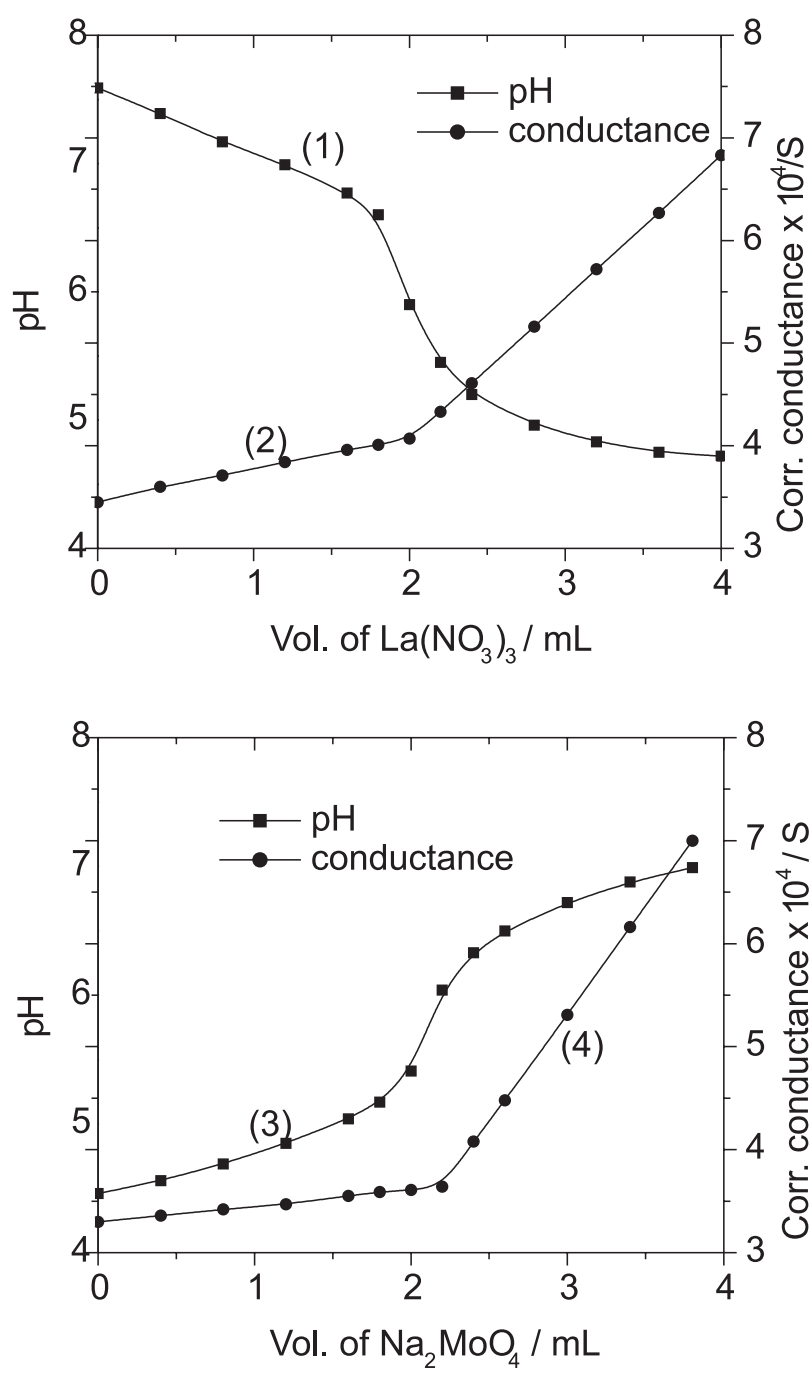

Figure 2. Normal-molybdate direct ( 1 and 2$)$ and reverse (3 and 4) titrations. 1, 2: $25 \mathrm{~mL}$ of $4.00 \times 10^{-3} \mathrm{~mol} \mathrm{~L}^{-1} \mathrm{Na}_{2} \mathrm{MoO}_{4}$ titrated with $3.33 \times 10^{-2} \mathrm{~mol} \mathrm{~L}^{-1} \mathrm{La}\left(\mathrm{NO}_{3}\right)_{3} 3,4: 25 \mathrm{~mL}$ of $2.86 \times 10^{-3} \mathrm{~mol} \mathrm{~L}^{-1}$ $\mathrm{La}\left(\mathrm{NO}_{3}\right)_{3}$ titrated with $5.00 \times 10^{-2} \mathrm{~mol} \mathrm{~L}^{-1} \mathrm{Na}_{2} \mathrm{MoO}_{4}$.

point when the last traces of lanthanum ions have been removed by precipitation, further addition of alkali molybdate causes a marked upward jump in $\mathrm{pH}$ and the inflection corresponds to the molar ratio for the formation of $\mathrm{La}_{2} \mathrm{O}_{3} \cdot 3 \mathrm{MoO}_{3}$ according to the reaction:

$$
2 \mathrm{La}\left(\mathrm{NO}_{3}\right)_{3}+3 \mathrm{Na}_{2} \mathrm{MoO}_{4}=\mathrm{La}_{2} \mathrm{O}_{3} \cdot 3 \mathrm{MoO}_{3}+6 \mathrm{NaNO}_{3}
$$

Employing similar concentrations of the reactants, direct (Figure 2, curve 2) and reverse (Figure 2, curve 4) conductometric titrations between the solutions of lanthanum nitrate and sodium molybdate gave welldefined breaks at 2:3 molar ratio of $\mathrm{La}^{3+}: \mathrm{MoO}_{4}{ }^{2-}$ confirming the formation of the same compound $\mathrm{La}_{2} \mathrm{O}_{3} \cdot 3 \mathrm{MoO}_{3}$ as indicated by the $\mathrm{pH}$ study.

\section{Lanthanum para-molybdate}

Sodium para-molybdate solution was prepared by addition of nitric acid to $\mathrm{Na}_{2} \mathrm{MoO}_{4}$ in molar ratio $8 \mathrm{H}: 7 \mathrm{Mo}$. Using different concentrations of Sodium para-molybdate (pH 5.5) and lanthanum nitrate ( $\mathrm{pH} 4.3$ ) solutions, a series of potentiometric titrations was carried out. In direct titrations (Figure 3, curve 1), when the para-molybdate solution was used as titre, a gradual change in $\mathrm{pH}$ value was observed till at the stoichiometric end-point a sharp downward jump in $\mathrm{pH}$ was observed when the molar ratio of $\mathrm{La}^{3+}: \mathrm{Mo}_{7} \mathrm{O}_{24}{ }^{6-}$ is $2: 1$ corresponding to the formation of lanthanum para-molybdate, $\mathrm{La}_{2} \mathrm{O}_{3} .7 \mathrm{MoO}_{3}$, in the neighborhood of $\mathrm{pH}$ 4.8. In case of inverse titrations (Figure 3 , curve 3 ), when lanthanum nitrate solution was used as titre, a gradual increase in $\mathrm{pH}$ was observed till at the stoichiometric point an upward jump in $\mathrm{pH}$ was noted and the inflection corresponds to the molar ratio for formation of $\mathrm{La}_{2} \mathrm{O}_{3} \cdot 7 \mathrm{MoO}_{3}$. The formation of the para-molybdate can be represented as follows:
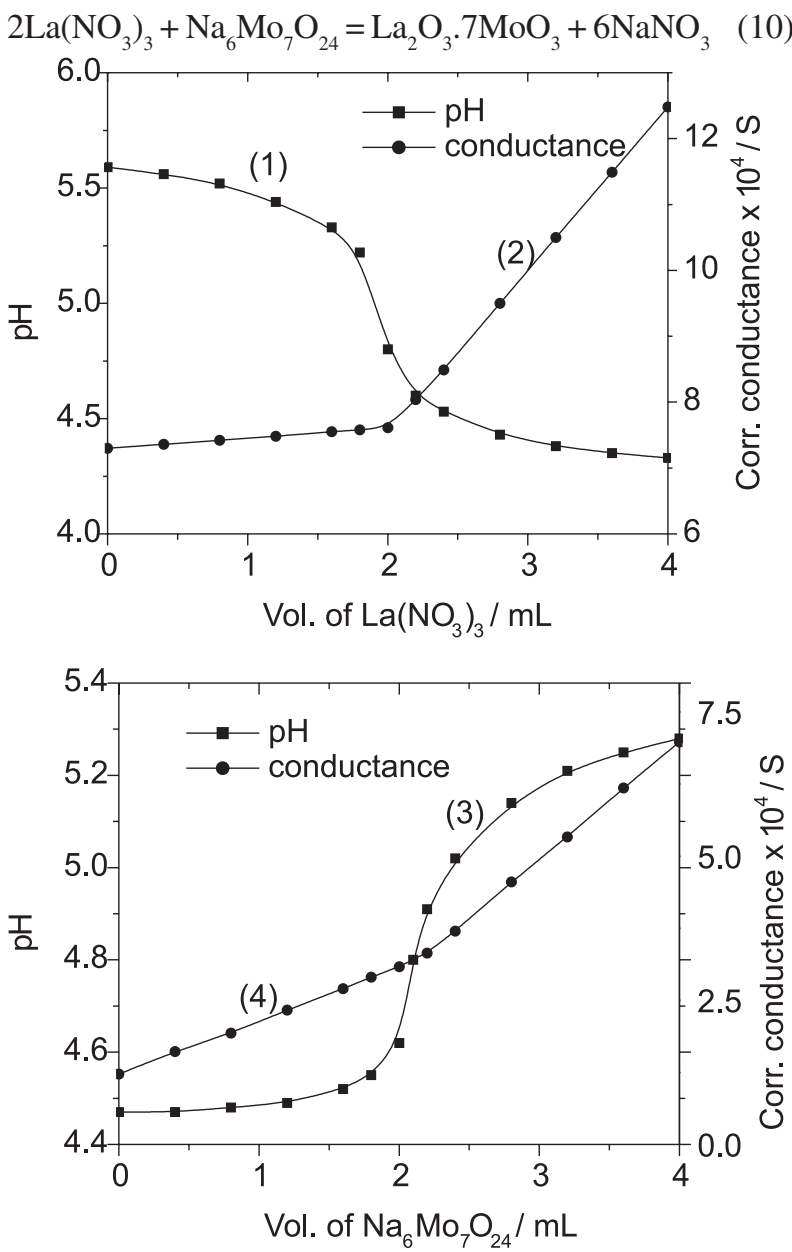

Figure 3. Para-molybdate direct (1 and 2) and reverse (3 and 4 ) titrations. 1, 2: $25 \mathrm{~mL}$ of $1.33 \times 10^{-3} \mathrm{~mol} \mathrm{~L}^{-1} \mathrm{Na}_{6} \mathrm{Mo}_{7} \mathrm{O}_{24}$ titrated with $3.33 \times 10^{-2} \mathrm{~mol} \mathrm{~L}^{-1} \mathrm{La}\left(\mathrm{NO}_{3}\right)_{3} 3$, $4: 25 \mathrm{~mL}$ of $1.11 \times 10^{-3} \mathrm{~mol} \mathrm{~L}^{-1}$ $\mathrm{La}\left(\mathrm{NO}_{3}\right)_{3}$ titrated with $6.67 \times 10^{-2} \mathrm{~mol} \mathrm{~L}^{-1} \mathrm{Na}_{6} \mathrm{Mo}_{7} \mathrm{O}_{24}$. 
Employing similar concentrations of the reactants a series of direct (Figure 3, curve 2) and reverse (Figure 3, curve 4) conductometric titrations was performed between the solutions of $\mathrm{La}\left(\mathrm{NO}_{3}\right)_{3}$ and $\mathrm{Na}_{6} \mathrm{Mo}_{7} \mathrm{O}_{24}$. The titration curves provide well-defined breaks at a point where the molar ratio of $\mathrm{La}^{3+}: \mathrm{Mo}_{7} \mathrm{O}_{24}{ }^{6-}$ is 2:1 (Table 2), thus confirming formation of para-molybdate, as suggested by the $\mathrm{pH}$ study.

\section{Lanthanum octa-molybdate}

Sodium octa-molybdate solution was prepared by addition of nitric acid to $\mathrm{Na}_{2} \mathrm{MoO}_{4}$ in molar ratio $3 \mathrm{H}: 2 \mathrm{Mo}$. Using different concentrations of the solutions of $\mathrm{La}\left(\mathrm{NO}_{3}\right)_{3}$ and $\mathrm{Na}_{4} \mathrm{Mo}_{8} \mathrm{O}_{26}$, a series of direct and reverse conductometric titrations was carried out. The nature of these titration curves (Figure 4) is similar to those of the para-molybdate. The curves provide well-defined inflections at molar ratio 4:3 of $\mathrm{La}^{3+}: \mathrm{Mo}_{8} \mathrm{O}_{26}{ }^{4-}$ corresponding to stoichiometry for formation of lanthanum octa-molybdate $2 \mathrm{La}_{2} \mathrm{O}_{3} \cdot 24 \mathrm{MoO}_{3}$ in the vicinity of $\mathrm{pH} 4.2$, according to the reaction:

$4 \mathrm{La}\left(\mathrm{NO}_{3}\right)_{3}+3 \mathrm{Na}_{4} \mathrm{Mo}_{8} \mathrm{O}_{26}=2 \mathrm{La}_{2} \mathrm{O}_{3} \cdot 24 \mathrm{MoO}_{3}+12 \mathrm{NaNO}_{3}$

The $\mathrm{pH}$ titrations of this system did not provide reliable results for the formation of lanthanum octa-molybdate, which may be ascribed to very close $\mathrm{pH}$ values of the solutions involved.

It was noted that after each addition of the titrant, it takes a little time for the $\mathrm{pH}$ and conductance values to become steady. A thorough stirring in the neighborhood of the equivalence point has a favorable effect. The presence

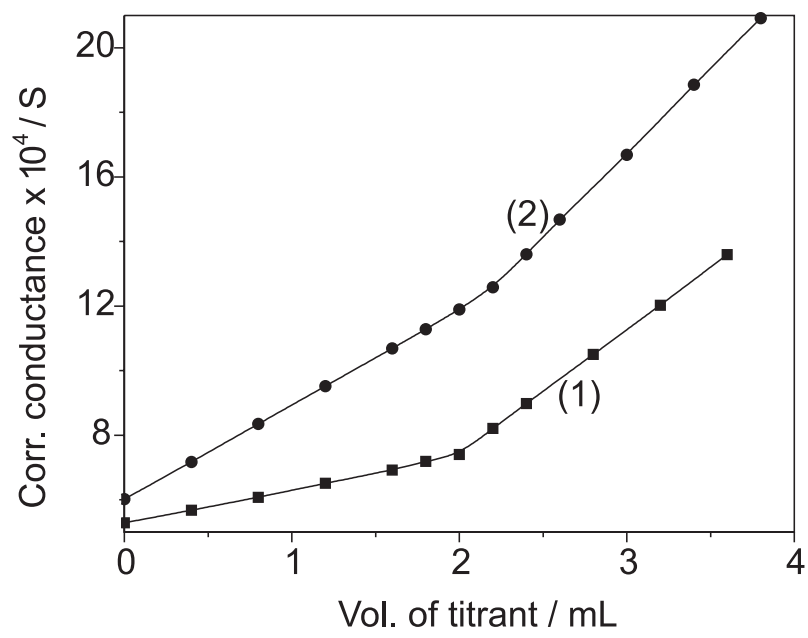

Figure 4. Octa-molybdate direct (1) and reverse (2) titrations. 1: $25 \mathrm{~mL}$ of $2.00 \times 10^{-3} \mathrm{~mol} \mathrm{~L}^{-1} \mathrm{Na}_{4} \mathrm{Mo}_{8} \mathrm{O}_{26}$ titrated with $3.33 \times 10^{-2} \mathrm{~mol} \mathrm{~L}^{-1}$ $\mathrm{La}\left(\mathrm{NO}_{3}\right)_{3} 2: 25 \mathrm{~mL}$ of $5.71 \times 10^{-3} \mathrm{~mol} \mathrm{~L}^{-1} \mathrm{La}\left(\mathrm{NO}_{3}\right)_{3}$ titrated with 5.00 x $10^{-2} \mathrm{~mol} \mathrm{~L}^{-1} \mathrm{Na}_{4} \mathrm{Mo}_{8} \mathrm{O}_{26}$. of ethanol (30\%) improves the position of end-point and increases the magnitude of the jump in $\mathrm{pH}$ curves as it decreases the solubility of the precipitates formed and minimizes hydrolysis and adsorption. The results obtained were precise. The relative standard deviation of the results reported in Table 2 was $<1 \%$.

\section{Quantitative analysis of precipitates}

The results of the quantitative elemental analyses of the precipitates were used to calculate the proportions of the elements present in the compounds. From these proportions, the composition of the compounds was established which was found to be the same as obtained by the electrometric techniques (see Table 3 ).

The present electrometric and analytical investigations confirm the formation and precipitation of three lanthanum molybdates viz. normal- $\mathrm{La}_{2} \mathrm{O}_{3} \cdot 3 \mathrm{MoO}_{3}$, para $-\mathrm{La}_{2} \mathrm{O}_{3} \cdot 7 \mathrm{MoO}_{3}$ and octa- $2 \mathrm{La}_{2} \mathrm{O}_{3} \cdot 24 \mathrm{MoO}_{3}$ in the vicinity of $\mathrm{pH} 5.9,4.8$ and 4.2 , respectively.

As structure of these compounds is not known they are represented as double oxide, the manner which is usually adopted for such compounds..$^{23,24}$

\section{Acknowledgement}

The authors are indebted to $\mathrm{CNPq}$ for financial assistance.

\section{References}

1. Haber, J.; The Role of Molybdenum in Catalysis; Climax Molybdenum Co: London, 1981.

2. Simpson, C.H.; Amer. Paint. Coating J. 1992, 66.

3. Kopf-Maier, P.; Klopotke, T.; J. Cancer Res. Clin. Oncol. 1992, 118, 216.

4. Jander, G.; Jahr, K.F.; Henkesheshoven, W.; Z. Anorg. Chem. 1930, 194, 383.

5. Bye, J.; Ann. Chim. Fr. 1945, 20, 463; ibid; C. R. Acad. Sci., Paris 1954, 238, 239; ibid; Bull. Soc. Chim. Fr. 1957, 1023.

6. Sasaki, Y.; Lindeqvist, I.; Sillen, L. G.; J. Inorg. Nucl. Chem. 1959, 9, 93.

7. Sasaki, Y.; Sillen, L.G.; Acta Chem. Scand. 1964, 18, 1014.

8. Sasaki, Y.; Sillen, L.G.; Ark. Khemi. 1968, 29, 253.

9. Aveston, J.; Anacker, E. W.; Johanson, J. S.; Inorg. Chem. 1964, 3, 735.

10. Ozeki, T.; Adachi H.; Ikeda, S.; Bull. Chem. Soc. Jpn. 1996, $69,619$.

11. Ozeki, T.; Kinoshita, Y.; Adachi, H.; Bull. Chem. Soc. Jpn. 1994, 67, 1041.

12. Pope, M. T. In Progress in Inorganic Chemistry; Lippard, S. 
J.; ed.; An Interscience Publication: New York, vol. 39, 1991.

13. Prasad, S.; Gonçalves, S.B.; Brito, J. B.; Cat. Today 2000, 57, 339.

14. Prasad, S.; Bull Electrochem. 1990, 6, 163.

15. Prasad, S.; Can. J. Chem. 1981, 59, 563.

16. Prasad, S.; Quim. Nova. 1994, 17, 31.

17. Prasad, S.; Gonçalves, S.B. J. Braz. Chem. Soc. 2000, 11, 199.

18. Vogel, A. I.; A Textbook of Quantitative Inorganic Analysis, $3^{\text {rd }}$ ed., Longmans: London, 1962, pp. 508, 238 and 541.

19. Honing, D.S.; Kustin, M.; Inorg. Chem. 1972, 11, 65.

20. Ozeki, T.; Kihara, H.; Hikima, G.; Anal. Chem. 1987, 59, 945.

21. Murata, K.; Ikeda, S.; Spectrochim. Acta 1983, 39A, 787.
22. Cruywagen, J.J.; Rohwer, E.F.C.H.; Inorg. Chem. 1975, 14, 3136.

23. Standen, A.; ed. In Kirk-Othmer Encyclopedia of Chemical Technology, $2^{\text {nd }}$. ed., Interscience Publishers: New York, 1967, vol. 13, p. 782.

24. Brauer, G., ed. In Handbook of Preparative Inorganic Chemistry, $2^{\text {nd }}$. ed., Academic Press: New York, 1965, vol. 2, p. 1705 .

Received: May 30, 2003 Published on the web: March 24, 2004 